\title{
Genetic variability of a population of Aedes aegypti from Paraná, Brazil, using the mitochondrial ND4 gene
}

\author{
Adriana L. Twerdochlib ${ }^{1}$, Ana C. Dalla Bona ${ }^{1}$, Selene S. Leite ${ }^{1}$, Rodrigo F. Chitolina ${ }^{1}$, \\ Betina Westphal ${ }^{1} \&$ Mario A. Navarro-Silva ${ }^{1,2}$
}

${ }^{1} \mathrm{CNPq}$ fellowship.

${ }^{2}$ Departamento de Zoologia, Universidade Federal do Paraná, Caixa Postal 19020, 81581-580 Curitiba-PR, Brasil. mnavarro@ufpr.br

\begin{abstract}
Genetic variability of a population of Aedes aegypti from Paraná, Brazil, using the mitochondrial ND4 gene. To analyze the genetic variability of populations of Aedes aegypti, 156 samples were collected from 10 municipalities in the state of Paraná, Brazil. A 311 base pairs (bp) region of the NADH dehydrogenase subunit 4 (ND4) mitochondrial gene was examined. An analysis of this fragment identified eight distinct haplotypes. The mean genetic diversity was high $(\mathrm{h}=0.702 ; \pi=0.01556)$. AMOVA analysis indicated that most of the variation (67\%) occurred within populations and the $\mathrm{F}_{\mathrm{ST}}$ value (0.32996) was highly significant. $\mathrm{F}_{\mathrm{ST}}$ values were significant in most comparisons among cities. The isolation by distance was not significant $(\mathrm{r}=-0.1216$ and $\mathrm{p}=0,7550$ ), indicating that genetic distance is not related to geographic distance. Neighbor-joining analysis showed two genetically distinct groups within Paraná. The DNA polymorphism and AMOVA data indicate a decreased gene flow in populations from Paraná, which can result in increased vectorial competence.
\end{abstract}

KEYWORDS. Aedes aegypti; genetic variability; mitochondrial DNA; genetic population; state of Paraná.

RESUMO. Variabilidade genética de uma população de Aedes aegypti do Paraná, Brasil, usando o gene mitocondrial ND4. Para analisar a variabilidade genética de populações de Aedes aegypti, 156 amostras foram coletadas em dez cidades do estado do Paraná, Brasil. Foi examinada a distribuição dos 311 pares de base do gene que codifica a subunidade 4 da enzima NADH desidrogenase. Pela amplificação e o sequenciamento deste fragmento foram identificados 8 haplótipos distintos. Os valores de diversidade genética foram altos $(\mathrm{h}=0.702 ; \mathrm{p}=0.01556)$. A análise de AMOVA indicou que a maior variação ocorreu dentro das populações com um valor de FST de 0.32996 altamente significativo. Valores de FST foram significativos na maior das comparações entre as cidades. $\mathrm{O}$ isolamento por distância não foi significativo $(\mathrm{r}=-0.1216 \mathrm{e} p=0.755)$, indicando que a distância genética não está relacionada a distância geográfica. A análise de Neighbor-joining mostrou dois grupos genéticos distintos dentro do estado do Paraná, grupo I e grupo II. O polimorfismo de DNA e os dados de AMOVA indicam decréscimo de fluxo gênico no estado do Paraná, o que pode resultar em aumento da competência vetorial da população.

PALAVRAS-CHAVE. Aedes aegypti; DNA mitocondrial; estado do Paraná; genética de populações; variabilidade genética.

Aedes (Stegomyia) aegypti (Linnaeus, 1762) has great epidemiological importance because it is the main vector of four serotypes of the dengue virus in urban areas. Aedes aegypti originated in the African continent (Ethiopic region). It arrived in the Americas aboard slave ships, became established and spread throughout the New World in the 17th and 18th centuries (OPAS 1995).

The distribution of Ae. aegypti covers the entire Brazilian territory. In the state of Paraná, the mosquito it is mainly found in regions with warm and wet climate (Forattini 2002). It is not well known when the pest first arrived in the state, although the first described cases of yellow fever date to the beginning of the 17th century (Roncaglio et al. 2001). In 1985, after supposed eradication from the country, Ae. aegypti was detected by Lopes et al. (1993) in Londrina, Paraná. The geographic distribution area of the mosquito has increased in the state since 1995. The increase in cases of dengue fever and hemorrhagic dengue, especially in the north and west regions of the state, occured because the vector has dispersed as a result of commercial trade, and also because solid residues from urban areas were not disposed of properly (Duque et al. 2010). Information on genetic variation within and between populations is important for outlining new strategies for local and regional vector control.

Since 1950, there have been advancements in genetic studies of mosquitoes, especially species of Aedes, Anopheles and Culex, generating information on chromosome numbers and heterochromatin distribution, as well as on genome size and organization (Rai 1999).

Several analyses have been undertaken using DNA sequences to evaluate genetic variability of Ae. aegypti. Extensive DNA-based genetic studies, using microsatellites (Huber et al. 2002), RFLP (restriction fragment length polymorphism) (Yan et al. 1998), and RAPD (Random Amplification of Polymorphic DNA) (Apostol et al. 1996; Gorrochotegui-Escalante et al. 2000; Sousa et al. 2001; Santos et al. 2003; Ocampo \& Wesson 2004; Paduan et al. 2006) were published. Ayres et al. (2003) assessed the genetic diversity of Ae. aegypti populations from five states in Brazil, employing 47 RAPD loci. Results of analyses revealed a high polymorphism and genetic differentiation among populations.

Mitochondrial DNA (mtDNA) is widely used as a genetic marker in population and evolutionary biology. It is generally 
assumed that the variation in mtDNA sequences is neutral with respect to fitness, and that the patterns of nucleotide variation can be used to infer the evolutionary histories of populations and closely related species (Fos et al. 1990; Nigro \& Prout 1990).

Mitochondrial DNA polymorphism is a widely used tool for assessing species gene flow (Excoffier 1992; Brower 1994, Birungi \& Munstermann 2002; Brito et al. 2002), and has been widely employed in population genetic studies of Ae. aegypti from different geographic regions, particularly where the dengue fever is endemic (Apostol 1996; Gorrochotegui-Escalante et al. 2000; Gorrochotegui-Escalante et al. 2002; Herrera et al. 2006).

The ND4 mitochondrial gene, which codifies the subunit 4 of the NADH dehydrogenase enzyme, is a great tool for analyzing genetic population structure and colonization events in Ae. aegypti. Such analyses were carried out in Mexico, Thailand, Peru, Venezuela, USA and Brazil (Gorrochotegui-Esclante et al. 2002; Bosio et al. 2005; Costa-da-Silva et al. 2005: Herrera et al. 2006; Bracco et al. 2007; Paduan \& Ribolla 2008; Urdaneta-Marquez et al. 2008; Lima-Júnior \& Scarpassa 2009).

The purpose of this study was to investigate, for first time, the genetic variability of Ae. aegypti populations from ten municipalities in Paraná, Brazil. For that purpose we employed DNA sequences of the ND4 gene.

\section{MATERIAL AND METHODS}

Mosquitoes collection. Populations were obtained from ten cities in the state of Paraná, south Brazil, as follows: Andirá, Bandeirantes, Barra do Jacaré, Floraí, Jacarezinho, Londrina, Maringá, Nova Londrina, Palotina, Paranavaí. A total of 156 individuals were collected. The collection sites are listed in Table I, and the geographical locations of all sampling sites are shown in Fig. 1.

Mosquito eggs were collected with ovitraps placed in several urban locations. Eggs were reared to the adult stage and a random sample of the adults was preserved in $100 \%$ ethyl alcohol and maintained at $-70^{\circ} \mathrm{C}$ for analysis.

DNA extraction, amplification and sequencing of ND4 gene. Individual mosquitoes were placed in $1.5 \mathrm{ml}$ microcentrifuge tubes, homogeneized with $160 \mu \mathrm{L}$ of lysis buffer (Tris HCL pH8,0 200 mM, NaCl 2,0 M, EDTA 70 pH 8.070 $\mathrm{mM}$ and sodium dodecyl sulfate $1 \%$ ) and incubated at $60^{\circ} \mathrm{C}$ for $30 \mathrm{~min}$ followed by addition of $50 \mu \mathrm{L}$ of chloroform: isoamilic (24:1). The mixture was centrifuged at $13000 \mathrm{~g}$ for 15 min. The DNA present in the supernatant was precipitated by ethanol. The final DNA pellet was reconstituted in TE buffer (10 mM Tris HCl, 1 mM EDTA pH 8.0) in a concentration of $20 \mathrm{ng} / \mu \mathrm{L}$ and stored at $-70^{\circ} \mathrm{C}$. DNA concentration was measured in NanoDrop 2000 spectrophotometer (Thermo Scientific).

DNA samples were used as templates to amplify a 336base-pair (bp) fragment of the mitochondrial ND4 gene. The primers used were NDA4: 5' - ATT GCC TAA GGC TCA TGT AG -3' and ND4R: 5'-TCG GCT TCC TAG TCG TTC AT -3' (Costa da Silva et al. 2005). In each experiment, a negative control was used. Polymerase chain reactions (PCR) were car-

Table I. Locations, geographical coordinates, and sample sizes of Aedes aegypti collections in the state of Paraná, Brazil.

\begin{tabular}{lcc}
\hline \multicolumn{1}{c}{ Municipality } & \multicolumn{1}{c}{ Latitude/Longitude } & Number of individuals \\
\hline Andirá & $23^{\circ} 02^{\prime} 40^{\prime \prime} \mathrm{S} / 50^{\circ} 1341^{\prime \prime} \mathrm{W}$ & 5 \\
Bandeirantes & $23^{\circ} 06^{\prime} 40^{\prime \prime} \mathrm{S} / 50^{\circ} 21^{\prime} 32^{\prime \prime} \mathrm{W}$ & 18 \\
Barra do Jacaré & $23^{\circ} 06^{\prime} 23^{\prime \prime} \mathrm{S} / 50^{\circ} 10^{\prime} 47^{\prime \prime} \mathrm{W}$ & 18 \\
Floraí & $23^{\circ} 17^{\prime} 04^{\prime \prime} \mathrm{S} / 52^{\circ} 18^{\prime} 14^{\prime \prime} \mathrm{W}$ & 18 \\
Jacarezinho & $23^{\circ} 09^{\prime} 43^{\prime \prime} \mathrm{S} / 49^{\circ} 58^{\prime} 11^{\prime \prime} \mathrm{W}$ & 26 \\
Londrina & $23^{\circ} 17^{\prime} 46^{\prime \prime} \mathrm{S} / 51^{\circ} 10^{\prime} 18^{\prime \prime} \mathrm{W}$ & 18 \\
Maringá & $23^{\circ} 25^{\prime} 08^{\prime \prime} \mathrm{S} / 51^{\circ} 56^{\prime} 40^{\prime \prime} \mathrm{W}$ & 20 \\
Nova Londrina & $22^{\circ} 46^{\prime} 25^{\prime \prime} \mathrm{S} / 52^{\circ} 59^{\prime} 18^{\prime \prime} \mathrm{W}$ & 4 \\
Palotina & $24^{\circ} 16^{\prime} 51^{\prime \prime} \mathrm{S} / 53^{\circ} 50^{\prime} 27^{\prime \prime} \mathrm{W}$ & 15 \\
Paranavaí & $23^{\circ} 01^{\prime} 21^{\prime \prime S} / 53^{\circ} 50^{\prime} 59^{\prime \prime} \mathrm{W}$ & 14 \\
\hline Total & & 156 \\
\hline
\end{tabular}

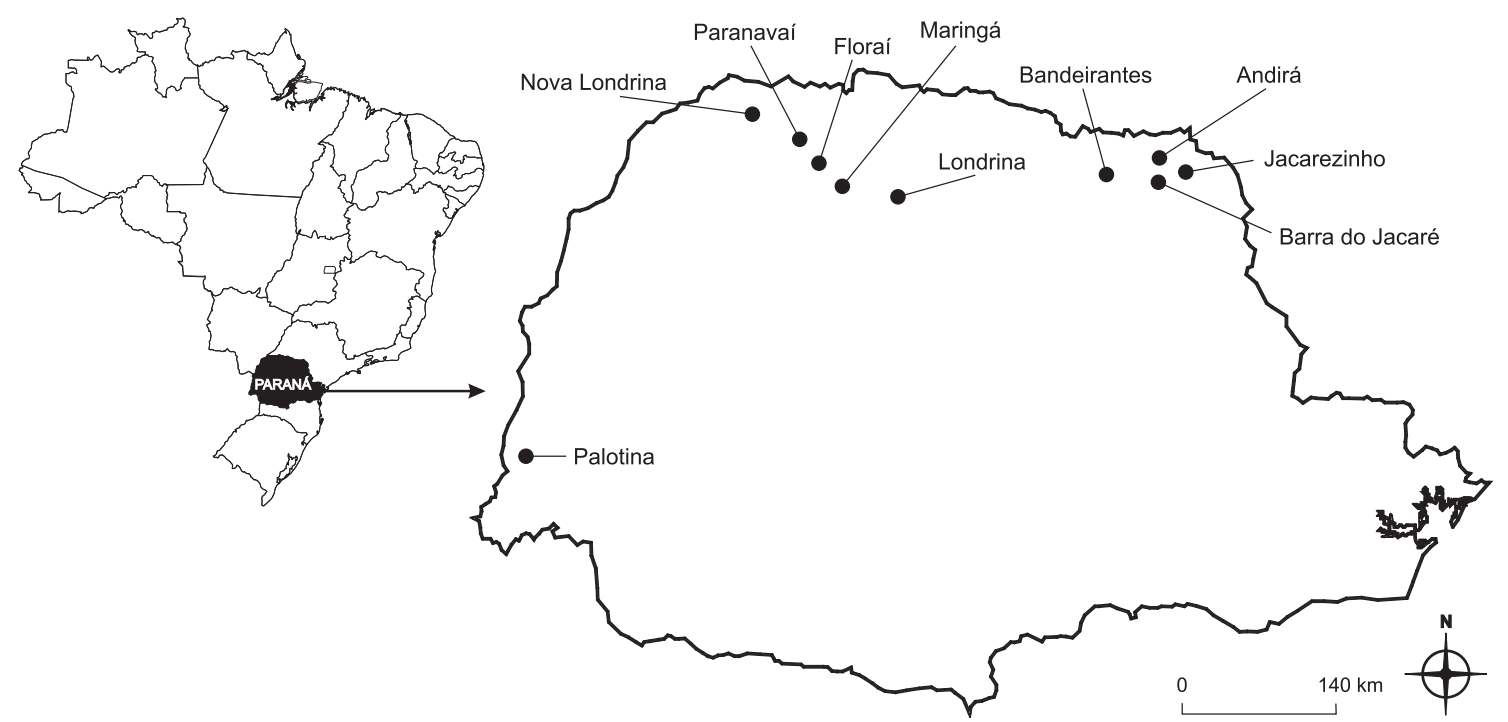

Fig. 1. Map of Brazil showing the state of Paraná and the sites where Aedes aegypti was collected. 
ried out in a total volume of $25 \mu \mathrm{L}$ using standard protocols, with $2 \mathrm{mM} \mathrm{Mg}{ }^{++}, 20 \mathrm{mM}$ Tris- $\mathrm{HCl}$ (pH 8.4), $50 \mathrm{mM} \mathrm{KCl}, 0.2$ mM dNTPs, 10 pmols of each primer, 1 U Taq DNA plymerase (SIGMA) and $1 \mu \mathrm{L}$ of template DNA. The PCR termocycler profile consisted of: initial denaturation at $96^{\circ} \mathrm{C}$ for $2 \mathrm{~min}$ followed by 35 cycles at $94^{\circ} \mathrm{C}$ for $1 \mathrm{~min}, 56^{\circ} \mathrm{C}$ for $30 \mathrm{~s}$, and $72^{\circ} \mathrm{C}$ for $1 \mathrm{~min}$, and final extension at $72^{\circ} \mathrm{C}$ for $7 \mathrm{~min}$. Each reaction was performed in AmpliTherm Thermal Cyclus. For sequencing, the PCR products were purified using QIAquick PCR Purification Kit (QIAGEN). Sequence reactions were carried out directly in both strands of DNA using ABI Big Dye chemistry (PE Applied Biosystems, Foster City, CA) and the sequences were generated with ABI 377 automated sequencer. The amplified ND4 region corresponds to $336 \mathrm{bp}$ at positions 8405 to 8741 in the Ae. aegypti mitochondrial genome (GenBank accession number NC_010241).

Statistical analysis. Consensus sequences were obtained with the Staden Package Program (Staden et al. 2001). These sequences were edited using the BioEdit Alignment Editor program (Hall 1999) and aligned in CLUSTAL X (Thompson et al. 1994). Haplotype genealogy based on the parsimony method was generated using the program TCS v. 1.21 (Clement et al. 2000). The DnaSP v.5 software (Rozas et al. 2003) was used to estimate the genetic diversity of the haplotypes $(h)$ and nucleotides (p), the number of variable sites (NV) and the average number of nucleotide differences $(K)$. Tajima's D (Tajima 1989) and Fu's Fs (Fu 1997) neutrality tests, as well haplotype and nucleotide differences $(K)$ and sequence divergence $(D)$, estimated between the haplotypes, were carried out using the DnaSP software.

The program Arlequin (Excoffier et al. 2006) was used to estimate genetic distance and gene flow using $F_{S T}$ and $N m$ values, respectively, and to perform a hierarchical analysis (AMOVA). The number of migrants per generation $(\mathrm{Nm})$ was obtained through $F_{S T}$ values using the formula $F_{S T}=1 / 2 \mathrm{Nm}+1$.

Mantel test (Mantel 1967) was used to estimate the correlation between genetic $\left(F_{S T}\right)$ and geographic $(\mathrm{km})$ distances. The IBDWS v. 3.3 software was used to test isolation by distance. Geographical distances for this analysis were obtained using Google Earth 6 (http://www.google.com. br/intl/pt-br/ earth/index.html).

We used Mega software (Tamura et al. 2007) to generate Neighbor-Joining (NJ) tree (Kumar et al. 2004) using the Kimura 2-parameter genetic distance model. Bootstrap support was estimated with 1000 replicates. Aedes albopictus (Skuse) (GenBank EF153761) and Culex quinquefasciatus Say (GenBank AY793692.1) were used as outgroups.

The haplotypes of this study are deposited in GenBank under accession JN089748-JN089755. They were compared with those of a previous study, from the Brazilian Amazon EU650405-EU650417 (Lima-Júnior \& Scarpassa 2009) Americas, Africa and Asia - DQ 176828 - DQ176831, DQ176833DQ176843 and DQ176845-DQ176849 (Bracco et al. 2007), Mexico AF334841-AF334865 (Gorrochotegui-Escalante et al. 2002) and Peru - DQ1777153-DQ177155 (Costa-da-Silva et al. 2005).

\section{RESULTS}

Distribution and frequency of haplotypes. The ND4 fragment contained $336 \mathrm{bp}$; however, only 311-bp were used for phylogenetic and population genetic analyses. A total of 156 individuals were sequenced. The analyses revealed the existence of eight haplotypes (H1, H2, H3, H4, H5, H6, H7 and H8) (Genbank accession number JN 089749 to JN 089755, respectively). The haplotypes showed 12 polymorphic sites, all informative (Table II), and were distinguished by eleven transitions $(\mathrm{C} \leftrightarrow \mathrm{T}$ or $\mathrm{G} \leftrightarrow \mathrm{A})$ at positions $48,53,83$, $98,131,176,215,224,233,254,293$ and by one single transversion $(\mathrm{A} \leftrightarrow \mathrm{T})$ at position 95 . The average nucleotide composition was $44.18 \% \mathrm{~A}, 28.29 \% \mathrm{~T}, 19.68 \% \mathrm{C}$, and $7.84 \% \mathrm{G}$, with a $\mathrm{G}+\mathrm{C}$ bias of $28.9 \%$.

Table II. Variable sites in eight haplotypes identified from a 311-bp fragment of the NADH dehydrogenase subunit 4 (ND4) mitochondrial gene.

\begin{tabular}{ccccccccccccc}
\hline Haplotypes & 48 & 53 & 83 & 95 & 98 & 131 & 176 & 215 & 224 & 233 & 254 & 293 \\
\hline H1 & $\mathrm{g}$ & $\mathrm{a}$ & $\mathrm{t}$ & $\mathrm{t}$ & $\mathrm{t}$ & $\mathrm{a}$ & $\mathrm{a}$ & $\mathrm{t}$ & $\mathrm{a}$ & $\mathrm{g}$ & $\mathrm{t}$ & $\mathrm{a}$ \\
H2 & $\mathrm{g}$ & $\mathrm{g}$ & $\mathrm{c}$ & $\mathrm{t}$ & $\mathrm{c}$ & $\mathrm{g}$ & $\mathrm{g}$ & $\mathrm{c}$ & $\mathrm{g}$ & $\mathrm{a}$ & $\mathrm{t}$ & $\mathrm{g}$ \\
H3 & $\mathrm{g}$ & $\mathrm{g}$ & $\mathrm{t}$ & $\mathrm{a}$ & $\mathrm{t}$ & $\mathrm{a}$ & $\mathrm{a}$ & $\mathrm{t}$ & $\mathrm{a}$ & $\mathrm{g}$ & $\mathrm{c}$ & $\mathrm{a}$ \\
H4 & $\mathrm{g}$ & $\mathrm{a}$ & $\mathrm{c}$ & $\mathrm{t}$ & $\mathrm{c}$ & $\mathrm{g}$ & $\mathrm{g}$ & $\mathrm{c}$ & $\mathrm{g}$ & $\mathrm{a}$ & $\mathrm{t}$ & $\mathrm{g}$ \\
H5 & $\mathrm{g}$ & $\mathrm{a}$ & $\mathrm{t}$ & $\mathrm{t}$ & $\mathrm{c}$ & $\mathrm{a}$ & $\mathrm{a}$ & $\mathrm{t}$ & $\mathrm{a}$ & $\mathrm{a}$ & $\mathrm{t}$ & $\mathrm{a}$ \\
H6 & $\mathrm{a}$ & $\mathrm{g}$ & $\mathrm{t}$ & $\mathrm{a}$ & $\mathrm{t}$ & $\mathrm{a}$ & $\mathrm{a}$ & $\mathrm{t}$ & $\mathrm{a}$ & $\mathrm{g}$ & $\mathrm{c}$ & $\mathrm{a}$ \\
H7 & $\mathrm{g}$ & $\mathrm{a}$ & $\mathrm{t}$ & $\mathrm{t}$ & $\mathrm{t}$ & $\mathrm{g}$ & $\mathrm{g}$ & $\mathrm{c}$ & $\mathrm{g}$ & $\mathrm{a}$ & $\mathrm{t}$ & $\mathrm{g}$ \\
H8 & $\mathrm{g}$ & $\mathrm{a}$ & $\mathrm{t}$ & $\mathrm{a}$ & $\mathrm{t}$ & $\mathrm{a}$ & $\mathrm{a}$ & $\mathrm{t}$ & $\mathrm{g}$ & $\mathrm{a}$ & $\mathrm{t}$ & $\mathrm{g}$ \\
\hline
\end{tabular}

The most frequent haplotype was haplotype $3(44.2 \%)$, followed by haplotype $1(23.7 \%)$ and haplotype $4(18 \%)$ (Table III). Haplotype 3 was found in all localities, except in Maringá. Haplotypes 5 and 8 were detected only in samples from Maringá, and haplotype 7 only in samples from Bandeirantes. In samples from Palotina, only haplotype 3 was detected.

Analysis of haplotype network. The analysis resulted in an unrooted network in which each mutational step is represented in Fig. 2 (Clement et al. 2000). Eight different groupings were defined: haplotype 1, haplotype 2, haplotype 3, haplotype 4 , haplotype 5 , haplotype 6 , haplotype 7 and haplotype 8 . Haplotype 3 , represented by a rectangle, is likely the oldest, being separated from H6, H1, H7, H8, H4, H2 and $\mathrm{H} 5$ by one, three, four, seven, eleven, twelve and eighteen mutational steps, respectively.

Genetic variability. The samples from Londrina showed the highest level of haplotype diversity, followed by Nova Londrina and Jacarezinho samples, $K=5.55,5.5$ and 4.5, respectively (Table IV). The highest level of nucleotide diversity was detected in the samples from Nova Londrina $(h=$ $0.83)$ and Londrina $(h=0.73)$. There was no haplotype and nucleotide variation in samples from Palotina.

Neutrality tests. Neutrality tests were applied in grouped and non-grouped Paraná populations. A significant deviation from the null hypothesis of neutrality was detected in 


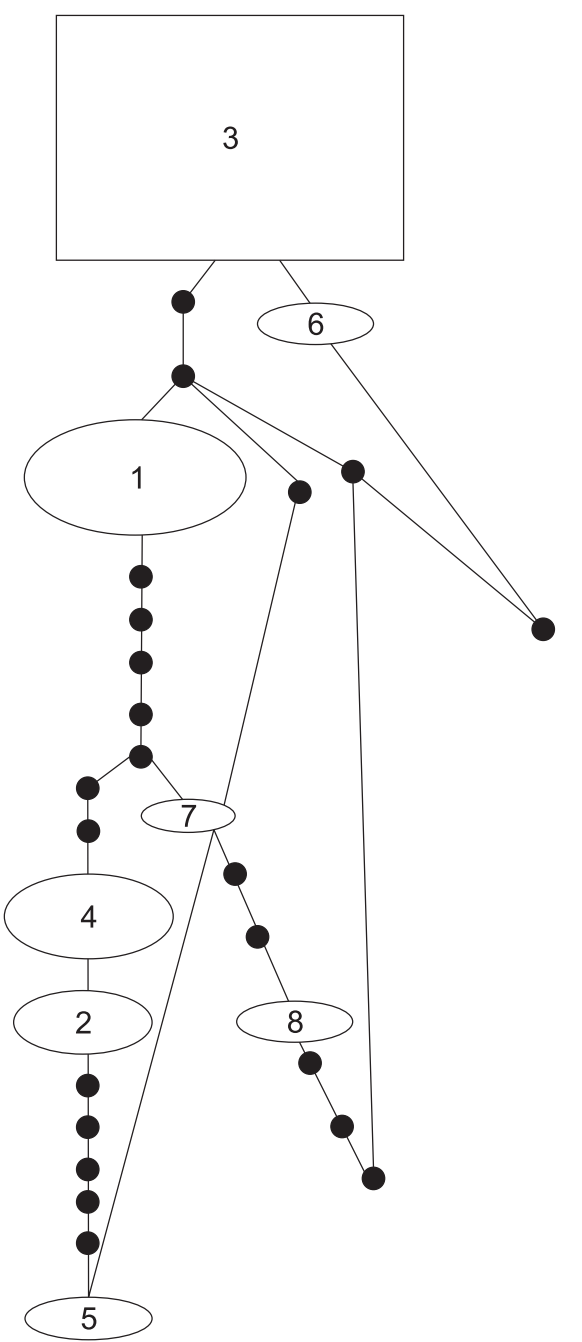

Fig. 2. Haplotype network of a 311 bp NADH dehydrogenase 4 region of mtDNA of 156 samples of Aedes aegypti. Each line in the network represents a single nucleotide mutation. The size of the ellipse is proportional to the number of individuals found for each haplotype. Blank circles indicate mutational steps between haplotypes. Numbers correspond to haplotypes referred to in the text and in the Table III.

test D (Table V) in the population from Londrina $(\mathrm{p}<0.01)$ when the populations are grouped $(\mathrm{p}<0.001)$. Fu and Li's $D$ test result was significant for the populations from Barra do Jacaré, Floraí, Jacarezinho $(\mathrm{p}<0.05)$. A significant deviation from neutrality was observed in the Fu and Li's $F$ test when the populations were grouped $(\mathrm{p}<0.02)$, and in the populations from Jacarezinho $(\mathrm{p}<0.02)$. Fu's $F$ s neutrality tests showed positive values in all samples.

Amova analysis. We performed AMOVA analysis, separating the populations according to their cities (Table VI). The greatest variation was within the populations themselves (67\%). Nevertheless, the percentage of variation was lower among samples (33\%). The results obtained for genetic distance $\left(F_{S T}=\right.$ 0.32996: $\mathrm{p}<0.05)$ indicate strong structuring. Most of the $F_{S T}$ values in comparisons among cities were significant (Table VII). Not considering the $F_{S T}$ values of Andirá and Nova Londrina, due the small size of the populations, the highest value of $F_{S T}$
Table III. Haplotype frequencies in ten Aedes aegypti populations, and haplotypes found in the published literature, using the NADH dehydrogenase subunit 4 (ND4) mitochondrial gene.

\begin{tabular}{lrrrrrrrrr}
\hline Municipality & H1 & H2 & H3 & H4 & H5 & H6 & H7 & H8 & Total \\
\hline Andirá & 1 & 0 & 3 & 1 & 0 & 0 & 0 & 0 & 5 \\
Bandeirantes & 10 & 6 & 1 & 0 & 0 & 0 & 1 & 0 & 18 \\
Barra do Jacaré & 0 & 1 & 14 & 3 & 0 & 0 & 0 & 0 & 18 \\
Floraí & 2 & 4 & 2 & 10 & 0 & 0 & 0 & 0 & 18 \\
Jacarezinho & 0 & 0 & 19 & 7 & 0 & 0 & 0 & 0 & 26 \\
Londrina & 5 & 0 & 5 & 7 & 0 & 1 & 0 & 0 & 18 \\
Maringá & 13 & 2 & 0 & 0 & 3 & 0 & 0 & 2 & 20 \\
Nova Londrina & 2 & 0 & 2 & 0 & 0 & 0 & 0 & 0 & 4 \\
Palotina & 0 & 0 & 15 & 0 & 0 & 0 & 0 & 0 & 15 \\
Paranavaí & 4 & 0 & 8 & 0 & 0 & 2 & 0 & 0 & 14 \\
\hline Total & 37 & 13 & 70 & 28 & 2 & 3 & 1 & 2 & 156 \\
\hline Percentage $(\%)^{2}$ & 23.7 & 8.3 & 44.9 & 18.0 & 1.3 & 1.9 & 0.06 & 1.3 & \\
\hline Amazon $^{1}$ & $\mathrm{H} 2$ & & $\mathrm{H} 6$ & $\mathrm{H} 10$ & & & & & \\
Peru $^{2}$ & & $\mathrm{H} 8$ & & & & & & & \\
AAA $^{3}$ & & & $\mathrm{H} 17$ & & & & & & \\
\hline
\end{tabular}

${ }^{1}$ Haplotypes from the Brazilian Amazon (Lima-Júnior \& Scarpassa 2009).

${ }^{2}$ Haplotype from Peru (Costa-da-Silva et al. 2006).

${ }^{3}$ Haplotype from Americas-Asia-Africa (Bracco et al. 2007).

Table IV. Genetic variability of ten populations of Aedes aegypti from the state of Paraná, Brazil, using the NADH dehydrogenase subunit 4 (ND4) mitochondrial gene.

\begin{tabular}{lcrccc}
\hline \multicolumn{1}{c}{ Population } & $\mathrm{NH}$ & $\mathrm{NV}$ & $\mathrm{K}$ & $\mathrm{h}$ & $\pi$ \\
\hline Andirá & 3 & 8 & 3.20 & 0.400 & 0.01000 \\
Bandeirantes & 4 & 11 & 4.29 & 0.610 & 0.01400 \\
Barra do Jacaré & 3 & 11 & 4.30 & 0.400 & 0.01300 \\
Floraí & 4 & 11 & 3.81 & 0.650 & 0.01200 \\
Jacarezinho & 2 & 11 & 4.50 & 0.410 & 0.01400 \\
Londrina & 4 & 12 & 5.55 & 0.730 & 0.01800 \\
Maringá & 4 & 5 & 1.40 & 0.560 & 0.00400 \\
Nova Londrina & 2 & 11 & 5.50 & 0.830 & 0.01700 \\
Palotina & 1 & 0 & $\mathrm{NC}$ & 0 & 0 \\
Paranavaí & 3 & 4 & 1.58 & 0.610 & 0.00500 \\
\hline All & 8 & 12 & 4.82 & 0.702 & 0.01556 \\
\hline
\end{tabular}

$\mathrm{NH}=$ Number of haplotypes; $\mathrm{NV}=$ Number of variable sites; $\mathrm{K}=$ average number of nucleotide differences; $h=$ haplotype diversity; $\pi=$ nucleotide diversity; $\mathrm{NC}=$ not calculated.

Table V. Neutrality tests of ten populations of Aedes aegypti from the state of Paraná, Brazil, using the NADH dehydrogenase subunit 4 (ND4) mitochondrial gene.

\begin{tabular}{lcccc}
\hline \multirow{2}{*}{ Population } & \multicolumn{4}{c}{ Tests } \\
\cline { 2 - 5 } & Tajima's $D$ & Fu and Li's $D$ & Fu and Li's $F$ & Fu's $F s$ \\
\hline Andirá & -1.7432 & -1.22979 & -1.17432 & 3.679 \\
Bandeirantes & 1.25099 & 0.16397 & 0.54427 & 4.435 \\
Barra do Jacaré & 1.00198 & $1.51783 * * *$ & 1.43825 & 5.976 \\
Floraí & 0.70641 & $1.42217 * * *$ & 1.43761 & 3.902 \\
Jacarezinho & 1.86643 & $1.82958^{* * *}$ & $1.43837 * *$ & 10.995 \\
Londrina & $2.18065 * * *$ & 1.06475 & 1.59603 & 5.748 \\
Maringá & -0.02030 & 1.18636 & 0.97968 & 0.803 \\
Nova Londrina & -0.83741 & -0.84240 & -0.83741 & 1.655 \\
Palotina & $\mathrm{NC}$ & $\mathrm{NC}$ & $\mathrm{NC}$ & $\mathrm{NC}$ \\
Paranavaí & 0.85013 & 1.16427 & 1.23298 & 1.931 \\
\hline All & $3.15744 *$ & 1.44835 & $2.47881 * *$ & 7.092 \\
\hline
\end{tabular}

$* \mathrm{p}<0.01 ; * * \mathrm{p}<0.02 ; * * * \mathrm{p}<0.05$. 
Table VI. Analysis of molecular variance in the frequency of the NADH dehydrogenase subunit 4 (ND4) mitochondrial gene haplotypes among Aedes aegypti populations from the state of Paraná, Brazil.

\begin{tabular}{lrrrc}
\hline $\begin{array}{c}\text { Source of } \\
\text { variation }\end{array}$ & d.f. & $\begin{array}{c}\text { Sum of } \\
\text { squares }\end{array}$ & $\begin{array}{c}\text { Variance } \\
\text { components }\end{array}$ & $\begin{array}{c}\text { Percentage } \\
\text { of variation }\end{array}$ \\
\hline Among population & 9 & 128.226 & $0.82139 \mathrm{Va}$ & 33.00 \\
Within population & 146 & 243.524 & $1.66797 \mathrm{Vb}$ & 67.00 \\
\hline Total & 155 & 371.750 & 2.48936 & \\
\hline Fixation índex $\mathrm{p}<0.05 . F_{S T}: 0.32996$. &
\end{tabular}

was observed among populations of Palotina vs. Maringá, because of the presence and absence of Haplotype 3, respectively.

Genetic isolation by distance. Pairwise linearized $F_{S T}$ values were regressed against pairwise geographic distance among populations to determine if gene flow among populations was correlated with geographic distance (i.e., to test for isolation by distance). The values found were $r=-0.1216$ and $\mathrm{p}=0.7550$, indicating no correlation between genetic and geographic distance among populations.

Phylogenetic analysis. The Neighbor-Joining clustering of eight haplotypes, using Aedes albopictus and Culex quinquefasciatus as outgroups, recovered two majors groups (Fig. 2). Group I is composed of five haplotypes: haplotype 3 , the most frequent (H3), haplotype $6(\mathrm{H} 6)$, haplotype 8 , observed only in Maringá samples, haplotype 1 (H1), the second most frequent (H1), and haplotype 5 (H5), which was also observed only in samples from Maringá. Group II is composed of three haplotypes: haplotype 4, the third most common (H4), haplotype 2, the fourth most common (H2), and haplotype $7(\mathrm{H} 7)$, the less frequent.

\section{DISCUSSION}

Populational parameters of genetic variability in our results showed that the specimens of Ae. aegypti collected in Paraná, Brazil, were similar to other insect populations that had already been assessed. The $\mathrm{G}+\mathrm{C}$ composition (28.9\%) of the obtained sequences is similar to that in the mtDNA of other insects (Clary \& Wolstenholme 1985; Bernasconi et al. 2000; Mirabello \& Conn 2006).

Our study is the first published in Brazil that shows the genetic variability of the ND4 in populations of Ae. aegypti in
Paraná. In a previous study, Bracco et al. (2007) sequenced the same fragment of the ND4 gene from two specimens from Foz do Iguaçu and three specimens from Maringá. Paduan \& Ribolla (2008) employed ten specimens from Londrina.

In the present study, eight haplotypes were detected. Haplotype 3, the most frequent (44.2\%), was not detected at all cities surveyed. This haplotype was absent from Maringá, although Bracco et al. (2007) had previously found it there. The cities where haplotype $\mathrm{H} 3$ was most frequent were Palotina $(100 \%)$ and Barra do Jacaré (77.7\%). In a study in the Americas, Bracco et al. (2007) found haplotype H3 (named as H17) in Ananindeua (Pará), Presidente Prudente (state of São Paulo) and Rio Branco (state of Acre), and observed that it is exclusive to Brazil, with wide distribution in the country. Paduan \& Ribolla (2008) detected haplotype H3 (named as H19) in Barretos (São Paulo) whereas Lima-Júnior \& Scarpassa (2009) found it in the Brazilian Amazon (named as H6), as the second most frequent in their study. Costa et al. also observed this haplotype in Brazil (named as H9) (unpublished data, but sequence on Gen Bank, accession EF153752). Haplotype H3 was not found either in Mexico (Gorrochotegi-Escalante et al. 2002) or in Peru (Costa-da-Silva et al. 2005). Therefore, in agreement with Lima-Júnior \& Scarpassa (2009), H3 may have originated in Brazil.

Haplotype 1 was the second most frequent (23.7\%) among the populations analyzed. This haplotype was absent from Barra do Jacaré, Jacarezinho and Palotina. Similarly to H3, H1 has been detected in only in Brazil, by Lima-Júnior \& Scarpassa (2009) in the Amazon Region, and by Paduan \& Ribolla (2008) in São Paulo. As haplotype 3, haplotype 1 may have arised in Brazil and is widely distributed in the country.

The third most frequent haplotype, $\mathrm{H} 4$, has previously detected in three studies in Brazil, Belém (state of Pará) (Lima-Júnior \& Scarpassa 2009) (as H10), Juazeiro do Norte (state of Ceará) (Paduan \& Ribolla 2008) (as clone 5). This haplotype has not been detected in populations from Mexico (Gorrochotegui-Escalante et al. 2002) and from Peru (Costada-Silva et al. 2005).

Haplotype 2, contrasting with the others, had only been previously detected in Peru (as H8) (Costa-da-Silva et al. 2005). This haplotype may have been introduced in Brazil from Peru because previous studies did not reveal its presence in the coun-

Table VII. Genetic distances (FST values) and effective number of migrants (Nm), above and below the diagonal, respectively, using the NADH dehydrogenase subunit 4 (ND4) mitochondrial gene, among populations of Aedes aegypti from the state of Paraná, Brazill.

\begin{tabular}{|c|c|c|c|c|c|c|c|c|}
\hline Population & Ban & Bar & Flo & $\mathrm{Jac}$ & Lon & Mar & Pal & Par \\
\hline Ban & - & $0.283^{*}$ & $0.206^{*}$ & $0.222 *$ & -0.008 & $0.224 *$ & $0.61 *$ & $0.432 *$ \\
\hline Bar & $1.27(18.5)$ & - & $0.466^{*}$ & -0.410 & $0.114^{*}$ & $0.314^{*}$ & 0.152 & 0.078 \\
\hline Flo & $1.92(199.1)$ & $0.57(216)$ & - & $0.398 *$ & $0.185^{*}$ & $0.622 *$ & $0.620^{*}$ & $0.669^{*}$ \\
\hline $\mathrm{Jac}$ & $1.75(37.1)$ & Inf. (22.4) & $0.75(237)$ & - & 0.068 & $0.265^{*}$ & $0.183 *$ & 0.103 \\
\hline Lon & Inf. (85) & 3.89 (104) & $2.20(115)$ & $6.85(122)$ & - & $0.209^{*}$ & $0.442 *$ & $0.340^{*}$ \\
\hline Mar & $1.09(162)$ & 1.09 (183) & $0.3(39.5)$ & $1.39(200)$ & $1.89(78.5)$ & - & $0.682 *$ & $0.340^{*}$ \\
\hline Pal & $0.32(370)$ & $2.79(386)$ & $0.3(188)$ & $2.23(401)$ & $0.63(290)$ & $0.23(215)$ & - & $0.240^{*}$ \\
\hline Par & $0.66(214)$ & $5.91(232)$ & $0.25(29.5)$ & 4.35 (249) & $0.97(112)$ & $0.97(66.6)$ & 1.58 (196) & - \\
\hline
\end{tabular}

Inf. = infinity; geographic distances $(\mathrm{km})$ are in parentheses. And = Andirá, Ban = Bandeirantes, Bar $=$ Barra do Jacaré, Flo $=$ Floraí, Jac $=$ Jacarezinho, Lon $=$ Londrina, Mar $=$ Marongá, $\mathrm{NL}=$ Nova Londrina, Pal $=$ Palotina, Par $=$ Paranavaí. $*$ p $>0.05$. 
try. Bottlenecks caused by insecticide treatments associated with strategies to reduce the number of immatures in larval habitats, are probably the causes of the presence of only four major haplotypes and four haplotypes with very small frequencies in collections from Paraná. Ayres et al. (2004), have reported that Brazilian populations of Ae. aegypti showed high levels of genetic differentiation in areas treated with chemical insecticide. In Paraná, the dengue mosquito has been exposed to insecticides for a long time. The intensive use of pyrethroids and organophosphates on adults, and Temephos, on larvae, had probably exerted selection pressure on the populations and caused severe bottlenecks during vector control efforts.

The values of genetic diversity found in this study were higher $(\mathrm{h}=0.702 ; \pi=0.01556)$ than for other species of mosquitoes, for instance Anopheles trinkae $(\mathrm{h}=0,559 ; \pi=0,0076)$ (Conn et al. 1997), Anopheles albimanus $(\pi=0,0045-0,0051)$ (de Merida et al. 1999) and Anopheles nuneztovari $(\mathrm{h}=0,564$; $\pi=0,0063$ ) (Scarpassa et al. 2000). In previous studies using the ND4 gene of Ae. aegypti, some values found for $\mathrm{h}$ and $\mathrm{p}$ were lower than those obtained in this study. Lima-Júnior \& Scarpassa (2009), studying populations from Amazon, estimated values for $\mathrm{h}=0,676$ and $\pi=0.0113$. Although LimaJúnior \& Scarpassa (2009) found a higher number of haplotypes than that observed in the present study, our results seem to indicate that Paraná populations can be older than those found in the Brazilian Amazon. Costa-da-Silva et al. (2005) studied three populations from Peru, and Bosio et al. (2005) evaluated 19 populations from Thailand, and found lower value for $\mathrm{p}$ (0.0079). Gorrochotegui-Escalante et al. (2002), studying populations from Mexico, found a $\pi=0.0143$. Higher values of nucleotide diversity than those presented herein were found in populations from Venezuela $(\pi=0.0187)$ (Herrera et al. 2006), Americas-Asia-Africa $(\pi=0.0199)$ (Bracco et al. 2007) and Brazil $(\pi=0.0174)$ (Paduan \& Ribola 2008). Analyzing each population of this study, Nova Londrina and Londrina showed the highest values of genetic diversity; however, the relatively smaller sample size from Nova Londrina $(\mathrm{n}=4)$ precludes inference on these parameters. Londrina is a densely populated commercial center with people constantly traveling in and out. This may contribute to the increase in gene flow between populations of Ae. aegypti.

The deviation from neutrality detected for grouped populations in test $\mathrm{D}^{*}$ (3.15744; $\left.\mathrm{p}>0.05\right)(\mathrm{Fu} \& \mathrm{Li} 1993)$ was positive but significant. Significantly positive results for deviation from neutrality are an indication of balancing selection or population substructure (Brito et al. 2002). In studies using mtDNA sequences, the neutral model is rejected when results of the test is significantly negative (Rand et al. 1994; Nachman 1998; Nielsen \& Weinreich 1999). The values of Fu's $F_{S}$ test, which is a great tool to assess population growth, were positive. A positive value of $F_{S}$ is an evidence of a recent population bottleneck or overdominant selection. $F_{S}$ is a more sensitive indicator of population expansion and genetic hitchhiking than Tajima's D (Fu 1997).

The AMOVA analysis, in which all the populations are grouped, showed that the most important component in the variability found is due to intrapopulational variation (67\%). This variation may be mostly related to the high levels of $p$ detected in populations from Londrina, Nova Londrina, Jacarezinho, Bandeirantes and Barra do Jacaré. On the other hand, the variation among populations was $33 \%$. The average $F_{S T}$ was 0.32996 , suggesting substantial genetic structure among populations.

Gene flow was low among Paraná populations $(\mathrm{Nm}=$ 1.062), despite the fact that most populations are situated less than $200 \mathrm{Km}$ apart from one another and share the four most frequent haplotypes. This result suggests significant populations structuring. Human movements can transport mosquito eggs among urban areas, thus increasing genetic similarity among geographically distant populations in northern Paraná. Similarly, Paduan et al. (2008) observed low rates of gene flow $(\mathrm{Nm}=0.96)$ for populations from southeastern Brazil, and some populations situated less than $250 \mathrm{Km}$ apart shared no haplotypes. In Mexico, Gorrochotegui-Escalante et al. (2002) found that gene flow among the populations decreases with increasing geographic distance. In the present study, excluding the populations from Andirá and Nova Londrina, the gene flow pattern is correlated with the frequencies of $\mathrm{H} 3$ and $\mathrm{H} 1$. The gene flow was extensive $(\mathrm{Nm}=$ infinite) among populations from Londrina vs. Bandeirantes $(80 \mathrm{Km})$ and Jacarezinho vs. Barra do Jacaré $(22.4 \mathrm{Km})$, probably, due to two factors: first, the short distance between the cities; and second, the high frequency of haplotypes H1 and $\mathrm{H} 3$, respectively.

Genetic isolation by distance, reflected in a decrease in similarity among populations as they become farther apart in space, was tested by Mantel test (Mantel 1967). Results of this test found no correlation $(\mathrm{r}=-0.1216$ and $\mathrm{p}=0.7550)$ between genetic and geographic distances. Based on this we concluded that gene flow in these populations is not affected by geographic distance.

In agreement with the results of previous studies (Gorrrochotegui-Escalante et al. 2002; Bosio et al. 2005; Herrera et al. 2006; Bracco et al. 2007; Paduan \& Ribolla 2008; LimaJúnior \& Scarpassa 2009) our neighbor-joining analysis of the haplotypes of Ae. aegypti in Paraná revealed two groups (I and II) (Fig. 3). Group I encompass the most frequent haplotypes, $\mathrm{H} 1$ and H3. This group is most likely older than group II. Group

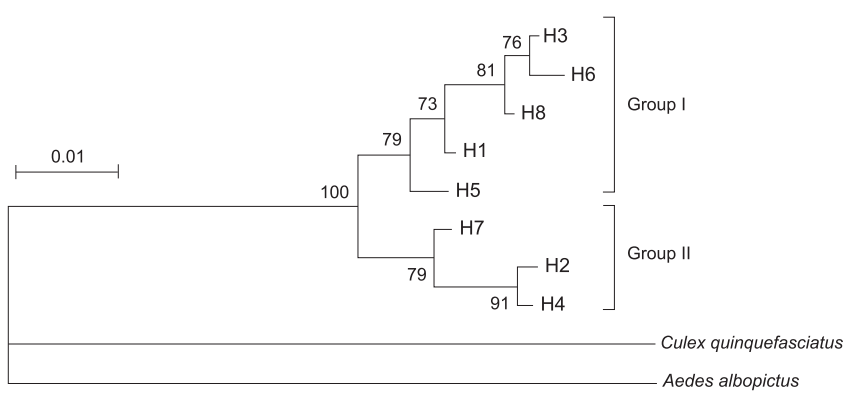

Fig. 3. Neighbor-joining (NJ) tree of Aedes aegypti haplotypes using the Kimura 2-parameter genetic distance model. Bootstrap values are marked under the respective nodes. 
I shared haplotypes with other Brazilian regions and group II shared one haplotype with Peru. These results are consistent with the presence of two genetic lineages within Paraná; group I (the older lineage) may have persisted independently of actions aimed to control vector populations.

\section{ACKNOWLEDGMENTS}

This work was supported by Conselho Nacional de Desenvolvimento Científico e Tecnológico (MCT/CNPq, Pronex Rede Dengue).

\section{REFERENCES}

Apostol, B. L.; W. C. Black IV; P. Reiter \& B. R. Miller. 1996. Population genetics with RAPD-PCR markers: the breeding structure of Aedes aegypti in Puerto Rico. Heredity 76: 325-334.

Ayres, C. E. J.; M. A. V. Melo-Santos; J. R. M. Prota; A. M. Solé-Cava; L Regis \& A. F. Furtado. 2004. Genetic structure of natural populations of Aedes aegypti at the micro- and macrogeographic levels in Brazil. Journal of the American Mosquito Control Association 20: 350-356.

Ayres, C. F. J.; M. A. V. Melo-Santos; A. M. Solé-Cava \& A. F. Furtado. 2003. Genetic differentiation of Aedes aegypti (Diptera, Culicidae), the major dengue vector in Brazil. Journal of Medical Entomology 40: 430-435.

Bernasconi, M. V.; C. Valsangiacomo; J. C. Piffaretti \& P. I. Ward. 2000. Phylogenetic relationships among Muscoidea (Diptera: Calyptratae) based on mitochondrial DNA sequences. Insect Molecular Biology 9: $67-74$.

Birungi, J. \& L. E. Mustermann. 2002. Genetic Structure of Aedes albopictus (Diptera: Culicidae) Populations Based on Mitochondrial ND5 Sequences: Evidence for an Independent Invasion into Brazil and United States. Annals of the Entomological Society of America 95: 125-132.

Bosio, C. F.; L. C. Harrington; J. W. Jones; R. Sithiprasasna; D. E. Norris \& T. W. Scott. 2005. Genetic Structure of Aedes aegypti Population in Thailand Using Mitochondrial DNA. American Journal of Tropical Medicine and Hygiene 72: 434-442.

Bracco, J. E.; M. L. Capurro; R. Lourenço-de-Oliveira \& M. A. M. Sallum. 2007. Genetic variability of Aedes aegypti in the Americas using a mitochondrial gene: evidence of multiple introductions. Memórias do Instituto Oswaldo Cruz 102: 573-580.

Brito, R. A. de; M. H. Manfrin \& F. M. Sene. 2002. Mitochondrial DNA phylogeography of Brazilian populations of Drosophila buzzatii. Genetics and Molecular Biology 25: 161 - 171

Brower, A. V. Z. 1994. Rapid morphological radiation and convergence among races of the butterfly Helicinius erato inferred from patterns of mitochondrial DNA evolution. Proceedings of the National Academy of Sciences 91: 6491-6495.

Clary, D. O. \& D. R. Wolstenholme. 1985. The mitochondrial DNA molecule of Drosophila yakuba: nucleotide sequence, gene organization, and genetic code. Journal of Molecular Evolution 22: 252-271.

Clemente, M.; D. Posada \& K. A. Crandall. 2000. TCS: A computer program to estimate gene genealogies. Molecular Ecology 9: 1657-1659.

Conn, J. E.; S. E. Mitchell \& A. F. Cockburn. 1997. Mitochondrial DNA variation within and between two species of neotropical anopheline mosquitoes (Diptera: Culicidae). Journal of Heredity 88: 98-107.

Costa-da-Silva, A. L. da; M. L Capurro \& J. E. Bracco. 2005. Genetic lineages in the yellow fever mosquito Aedes (Stegomyia) aegypti (Diptera: Culicidae) from Peru. Memórias do Instituto Oswaldo Cruz 100: 539-544.

de Merida, A. M. P.; M. Palmieri; Yurrita, M. M.; Molina, A.; Molina E.; Black IV, W.C. 1999. Mitochondrial DNA variation among Anopheles albimanus localities. American Journal of Tropical Medicine and Hygiene 61: 230-239.
Duque, J. E.; R. V. Silva da; E. F. Kuwabara \& M. A. Navarro-Silva. 2010. Dengue no Estado do Paraná, Brasil: distribuição temporal e espacial no período de 1995-2007. Salud UIS 42: 113-122.

Excoffier, L.; G. Laval \& S. Schneider. 2006. Arlequin (version 3.0): An integrated software package for population genetics data analysis. Evolutionary Bioinformatics Online 2005: 47-50 (accessed 17 May 2012).

Forattini, O. P. 2002. Culicidologia Médica. Volume 2. São Paulo, Edusp, 864 p.

Fos, M.; M. A. Domínguez; A. Latorre \& A. Moyá. 1990 Mitochondrial DNA evolution in experimental populations of Drosophila subobscura. Proceedings of the National Academy of Science 87: 4198-4201.

Fu, Y. X. 1997. Statistical tests of neutrality of mutations against population growth, hitchhiking, and background selection. Genetics 147: 915925.

Fu, Y. X. \& W. H. Li. 1993. Statistical tests of neutrality mutations. Genetics 133: 693-709.

Gorrochotegui-Escalante, N.; M. da L. Munoz; I. Fernandez-Salas; B. J. Beaty \& W. C Black IV. 2000. Genetic isolation by distance among Aedes aegypti populations along the northeastern coast of Mexico. American Journal of Tropical Medicine and Hygiene 62: 200-209.

Gorrochotegui-Escalante, N.; C. Gomez-Machorro; S. Lozano-Fuentes; I. Fernandez-Salas; M. da L. Munoz; J. A. Farfan-Ale; J. Garcia-Rejon; B. J. Beaty \& W. C. Black IV. 2002. Breeding structure of Aedes aegypti populations in Mexico varies by region. American Journal of Tropical Medicine and Hygiene 66: 213-222.

Hall, T. A. 1999. BioEdit: a user-friendly biological sequence alignment editor and analysis program for Windows 95/98/NT. Nucleic Acids Symposium Series 41: 95-98.

Herrera, F.; L. Urdaneta; J. Rivero; N. Zoghbi; J. Ruiz; G. Carrasquel; J. A. Martínez; M. Pernalete; P. Villegas; A. Montoya; Y. Rubio-Palis \& E. Rojas. 2006. Population genetic structure of the dengue mosquito Aedes aegypti in Venezuela. Memórias do Instituto Oswaldo Cruz 101: 625-633.

Huber, K.; L. L. Loan; T. H. Hoang; S. Ravel; F. Rodhain \& A. B. Failloux. 2002. Genetic differentiation of the dengue vector, Aedes aegypti (Ho Chi Minh City, Vietnam) using microsatellite markers. Molecular Ecology 11: 1629-1635.

Kumar, S.; K. Tamura \& M. Nei. 2004. MEGA 3: Integrated software of molecular evolutionary genetics analysis and sequence alignment. Briefing in Bioinformatics 5: 150-163.

Lima-Júnior, R. S. \& V. M. Scarpassa. 2009. Evidence of two lineages of the dengue vector Aedes aegypti in the Brazilian Amazon, based on mitochondrial DNA ND4 gene sequences. Genetics and Molecular Biology 32: 414-422.

Lopes, J.; M. A. N. Silva; A. M. Borsato; V. D. R. B. Oliveira \& F. J. de A Oliveira, 1993. Aedes (Stegomyia) aegypti e a culicedeofauna associada à área urbana da região sul, Brasil. Revista de Saúde Pública 27: 326-33.

Mirabello, L. \& J. E. Conn. 2006. Molecular population genetics of the malaria vector Anopheles darlingi in Central and South America. Heredity 96: 311-321.

Nachman, M. W. 1998. Deleterious mutations in animal mitochondrial DNA. Genetica 102/103: $61-69$.

Nigro, L. \& T. Prout. 1990. Is there selection on RFLP differences in mitochondrial DNA? Genetics 125: 551-555.

Nielsen, R. \& D. M. Weinreich. 1999. The age of nonsynonymous and synonymous mutations in animal mtDNA and implications for the mildly deleterious theory. Genetics 153: 497-506.

Mantel, N. 1967. The detection of disease clustering and a generalized regression approach. Cancer Research 27: 209-220.

Ocampo, C. B. \& D. M. Wesson. 2004. Population dynamics of Aedes aegypti from a dengue hyperendemic urban setting in Colombia. American Journal of Tropical Medicine and Hygiene 71: 506-513.

Organización Panamericana de la Salud. 1995. Dengue y dengue hemorrágico en las Américas: guias para su prevención y control. Publicación Científica no. 548, Washington DC, Organización Panamericana de la Salud, $109 \mathrm{p}$.

Paduan, K. dos S.; J. P. Araújo-Júnior \& P. E. M. Ribolla. 2006. Genetic variability in geographical populations of Aedes aegypti (Diptera, 
Culicidae) in Brazil elucidated by molecular markers. Genetics and Molecular Biology 29: 391-395.

Paduan K. dos S. \& P. E. M. Ribolla. 2008. Mitochondrial DNA polymorphism and heteroplasmy in populations of Aedes aegypti in Brazil. Journal of Medical Entomology 45: 59-67.

Rai, K. S. 1999. Genetics of mosquitoes. Journal of Genetics 78: 163-169. Rand, D. M.; M. Dorfsman \& L. M. Kann. 1994. Neutral and non-neutral evolution of drosophila mitochondrial DNA. Genetics 138: 741-756.

Roncaglio, C.; M. Neuert \& M. A. Borges Martins. 2001. Notes for a history of health: document sources of Paraná. História, Ciências, SaúdeManguinhos 8: 223-235.

Rozas, J.; J. C. Sánchez-DelBarrio; X. Messeguer \& R. Rozas. 2003. DnaSP, DNA polymorphism analyses by the coalescent and other methods. Bioinformatics 19: 2496-2497.

Scarpassa, V. M.; S. Geurgas; A. M. L. Azeredo-Espin \& W. P. Tadei. 2000 Genetic divergence in mitochondrial DNA of Anopheles nuneztovari (Diptera: Culicidae) from Brasil and Colômbia. Genetics and Molecular Biology 23: 71-78.

Santos, V. M. dos; M. de L. da G. Macoris; M. T. M. Andrighetti; P. E. Ávila \& K. Kirchgatter. 2003. Analysis of genetic relatedness between populations of Aedes aegypti from different geographic regions of São Paulo State, Brazil. Revista do Instituto de Medicina Tropical de São Paulo 45: 99-101.
Sousa, G. B. de; A. Blanco \& C. N. Gardenal. 2001. Genetic relationships among Aedes aegypti (Diptera: Culicidae) populations from Argentina using random amplified polymorphic DNA polymerase chain reaction markers. Journal of Medical Entomology 38: 371-375.

Staden, R.; D. P. Judge \& J. K. Bonfield. 2001. Sequence assembly and finishing methods. Methods of Biochemical Analysis 43: 303-322.

Tamura, K.; J. Dudley; M. Nei \& S. Kumar. 2007. MEGA4: Molecular Evolutionary Genetics Analysis (MEGA) software version 4.0. Molecular Biology and Evolution 24: 1596-1599.

Tajima, F. 1989. Statistical Method for Testing the Neutral Mutation Hypothesis by DNA Polymorphism. Genetics 123: 585-595.

Thompson, J. D.; D. G. Higgins \& T. J. Gibson. 1994. Clustal W: improving the sensitivity of progressive multiple sequence alignment through sequence weighting, position-specific gap penalties and weight matrix choice. Nucleic Acids Research 11: 4673-4680.

Urdaneta-Marquez, L.; C. Bosio; F. Herrera; Y. Rubio-Palis; M. Salasek \& W. C. Black IV. 2008. Genetic relationships among Aedes aegypti collections in Venezuela as determined by mitochondrial DNA variation and nuclear single nucleotide polymorphisms. American Journal of Tropical Medicine and Hygiene 78: 479-491.

Yan, G.; D. D. Chadee \& D. W. Severson. 1998. Evidence for genetic hitchhiking effect associated with insecticide resistance in Aedes aegypti. Genetics 148: 793-800.

Received 5/9/2011; accepted 19/5/2012

Editor: Maria Anice Mureb Sallum 